\title{
Financial Crime, ICT \& E-Governance: Libraries Role
}

\author{
K. Olowu \\ Nigeria Institute of Advanced Legal Studies, \\ University of Lagos, Akoka, Lagos. \\ P. Gabasa \\ Nigeria Institute of Advanced Legal Studies, \\ University of Lagos, Akoka, Lagos.
}

\begin{abstract}
Love of money is the root of all evil (I Tim. 6:10) More than thirty financial crime are listed in this work making it like a spaghetti bowl. The list is inexhaustive with aid of ICT which is simply "putting old wine in new bottles" Elements of financial crime, consequences of these on the society and leeway for escape from justice in this climate are listed. From clumsy adjudication, corruption in judiciary, in availability of experts ,nonexistence of e-governance, dead forensic laboratories to empower Questioned Documents Examination (QDE), dearth of criminal profiling, jurisdictional discrepancies due to extra territoriality of the crime, short lifespan of cyber storage devices and double standards of investigatory unit, to difficulty of physical presence of suspects of borderless crimes. Overcoming these impediments are herculean but attainable. Recommendations to stem these crime's negative effects on the economy and distortion of social stability etc. range from punishments bothering on cruelty and inhumanity like South Korea's death penalty, documentation of financial criminals globally and information dissemination on such. Treaties on such crimes should be published widely, resuscitation of forensic laboratories to empower analysis of disputed signatures, fingerprints of ex-convicts.(CCR), Cross fertilization of ideas by jurists in foreign lands and reports in law libraries. Possibilities in virtual environments via ICT are listed such as "FinTrack" software etc. to stem this unethical public, financial behaviour.
\end{abstract}

Keywords: Financial crime, Information technology, Cross border crime

\section{Financial Crimes}

KEYWORDS: FINANCIAL CRIME, ICT, CROSS BORDER, E-GOVERNANCE'

Cheque fraud (signature. embellishments, alterations, etc). Credit card fraud, Ponzi schemes /pyramid builder (MMM), market manipulation, confidence tricks, tax evasion, financing terrorism (undercover fraud), insurance frauds, corporate frauds (Cadbury, Intercontinental bank and other planned bankruptcy), medical claims, securities, insider trading, unsound business, smuggling (endangering local industries), P.O.S. theft, scams, bribery, creative accounts, omissions/exaggeration / misstatement of facts. Ghost workers, moonlighting, computer frauds (cybercrirne), EFT, cheating, lying, advance fee fraud (419) official corruption, bid/ procurement rigging, criminal illicit simulation, receiving stolen property, food adulteration, charity scams, drug chains/ baron, social security fraud, salami virus, embezzlements, larceny by trick, other false pretense. deceptive trade practices, suppression of entries ,supply chain fraud, extortion, financial scams, fictitious school receipts/admission, teaming and lading, round tripping, lazy Susan, theft of confidential information, cybercrime. Looting, racketeering, bunkering, impersonation, over pricing, marriage/love scams. offshore laundering, inflated salary, gambling, shoplifting, etc. 


\section{Elements Of Fraud}

* Intent (mens rea) No need to prove/ private

* Proceeds confer benefit on trustee. employer or fiduciary agent without employer's or principal's consent

* Offer or soliciting for bribe (At times mutual agreement) (Actualization immaterial).

\section{ICT}

Management of information with computer tools. Virtual crime is 'old wine in new bottles' and include: Tampering with computer documents, hacking, e-obscenity, experts' refusal to decrypt encrypted mess for fraudulent purposes. Misrepresentation/suppression of material facts, publication of digital signature (cryptography) for fraud, denial of service ( with cyber gauge). Defamation,, email spanning and spoofing, privacy invasion, theft of source code/ data/ software, marketable info. (trade secret/codes), unlawful access to records. EFT, stock transfer, c-commerce, telecom fraud, virus invasion, cyber terror/warfare, cvber stalking, espionage, cyber piracy, spamming (junk), etc.

\section{METHODOLOGY}

Primary source was not consulted as investigators took Oath of office of Secrecy and criminals always insist on innocence even upon glaring conviction Only literature search and insider view of investigation were exploited

\section{Leeway To Financial Crime}

* Excessively cumbersome procedural rules- interlocutory injunction, Frontload, ADR/ public intervention, ,nolle prosequi, loss of evidence/suspect. etc

* Corruption in the judicial /investigatorv aims.

* Porous borders/ ECOWAS Movt Treaty/Lack of forensic database

* Mournful remedy to an epidemic of disaster magnitude

* Dearth of forensic/questioned document laboratories in Nigeria

* Limitation of human/financial aids for investigation

* Primitive modus operandi for investigation-torture.

* Non admission of digital evidence in court prior 2011

* Dearth of ICT experts.

\section{E-GOVERNANCE}

Tertiary education has been the incubators of great innovation ditto for e-governance in Nigeria. Much as the super highway has assisted every human endeavour, not only the university system but the three arms of government have been left behind. E-governance is made up of filling and paying taxes online, locating medicare, complaints channels, accessing government information online, etc. That is to say application of ICT to governance be it for census, planning, electoral collation, resources, infrastructural development, voting, and so on. Judges adjourns your case till he wears litigants out because his registrar asks for the 'dole' which one would not understand at first. To promote meaningful use of ICT in governance, utilization of digitals must be used in governance to modernize and make information readily disseminated to the governed. Opeibi (2018:82) advises that for ICT to drive operational efficiency, improve quality of governance, citizen/social welfare, the meaning of municipality must be synonymous with smart city. (Quoted from http.//internetof thingsagenda.techtarget.compefinitionsmart-city).

Government acts are not driven anywhere by ICT not even in the most metropolitan Lagos. The underpinning seems to be corruption as access to government held information will create openness, maximize revenue (IGR) and minimize expenditure. 
The down side of e-governance is high demand for ethical standards, privacy policy, compliance, etc. Monitoring mechanisms to vet what is being posted in a society where more than half are illiterate is herculean as consuming everything is via oral sources. Smart city project or e-governance must have first tackled misuse of critical data, identity theft, unauthorized access, misuse of personal information, and all other cybercrime.

\section{Consequences Of Financial Crime On Governance}

* Perilous than all violent crime in unison

* Goals inconsistent with perceived duties and Oath of office

* Makes a criminal of all citizens

* Highly professionalized (negatively)

* Creates milieu inimical to development

* Complexity and invisibility of crime makes mockery/impedes investigation

* Ease of doing business earns abysmal ranking for concerned nations

* Negative impact on micro/macro- economics (World Bank IMF Report of 2013)

* Social distortion as illicit funds mix with legally earned income (Goods overpricing, immorality)

* Insecurity through terror financing by launderers

* Foreclose integration of guilty nations to global financial market

* Widens gaps between "haves" \& "have- nots"

* Tarnishes innocent citizens' reputation

* Derelicts social public utilities

* Impedes ICT's ease of globalization and business

\section{Libraries and criminal investigation.}

- Hypothetical cases ease methodical teaching of law, that is precedents in local and foreign courts to aid comparative study. Showcasing legal regulations in old social and economic life, hitherto devoid of regimental laws.

- Emergence of new social laws from all clinics like Proceeds of Crime Act 2002

- Books and monographs on all subjects

- Law reports of Commonwealth/Non-Commonwealth for consultation by jurists

- Law reports of judgments from superior and inferior courts to keep track of litigations

- Government publications reporting all government activities

- Press clippings (soft book) of financial crime related or investigative journalism resources (magazines. TV interviews, Dailies)

- Journal articles of scholarly publications on financial crime tagged .

\section{RECOMMENDATIONS}

* Inter professional cooperation among all units

* E-enabling interactive sessions with leaders

* Post-tenure asset tracing enquiries/ Forfeiture of Assets after conviction

* Repeal of Public officers' Protection Act/ S..308 of 1999 Constitution

* Embryonic state of ICT calls for policy engagement of ICT experts, forensic auditors (CCR/spectroscopy)

* Diligent resources/vote for implementation of MLAT,

UNITAR, WALFEM, MEFIM, OHADA,, (all regional/international Treaties)

* Repatriation, rendition, extradition, rejection of asylum should be of universality principle.

* Staff/equipment upgrade for machine aided/electronic evidence

* Deprivation of life for convicts as in South. Korea. 


\section{References}

Kataria, R.P. \& Srinivas, SKP (2013). Cvbercrimes: Cyber evidence. New Delhi, Orient PubI. Coy.1st ed. 122.

Fieth, Mark \& Aiolfi, Germma (2004). Comparative Guide to Anti-money laundering:: Cheltenham, Edward Elgar $10-436$.

National District Attorneys' Association Prosecutors manual on economic crime. 1974 Chamber of commerce of USA. Handbook on white-collar crime.

Goldspink, R. \& Cole, J. (2002). Int. commercial fraud 1st ed. London. Sweet \& Maxwell, 129.

The Guardian. 20/10/15 .P. 57. Cumbersome procedural rules.

The Punch 26/04 /17 P.33 Dearth of skill limits fight against cyber attack 